\title{
The Compliance to Human Rights in Business Sector: Focusing on Banks
}

\author{
Marta Bordignon
}

Published online: 29 November 2012

(C) CEEUN 2012

\begin{abstract}
The position of the financial sector in respect to potential human rights abuses deserves special attention. In fact, banks can directly abuse the human rights of their employees and customers. This issue has obtained new attention at the global level with the adoption of the UN Human Rights Council of the Guiding Principles on Business and Human Rights: Implementing the United Nations 'Protect, Respect and Remedy' Framework proposed by John Ruggie, the Special Representative of the UN Secretary General on the issue of human rights and transnational corporations and other business enterprises. This document underlines the relevance of the term 'complicity' in respect to its legal and nonlegal value, in particular for identifying the level of liability of a bank in an alleged human rights abuse. In this regard, it is also important to consider the role of some national and international subjects such as NGOs, Export Credit Agencies and Rating Agencies, in determining the compliance parameters and the eventual motivations for exclusion of a bank from the international financial and social scenario.
\end{abstract}

Keywords Human rights $\cdot$ Business $\cdot$ Compliance $\cdot$ Due diligence $\cdot$ Banks

\section{Introduction}

The issue of the business compliance with human rights principles and norms entered a new era with the endorsement by the UN Human Rights Council of the Guiding Principles on Business and Human Rights: Implementing the United Nations 'Protect, Respect and Remedy' Framework proposed by John Ruggie, the Special Representative of the UN Secretary General on the issue of human rights

M. Bordignon ( $\square)$

International Law, University of Rome "Tor Vergata", Rome, Italy

e-mail: marta.bordignon@uniroma2.it 
and transnational corporations and other business enterprises. ${ }^{1}$ Such Guiding Principles and the Framework provide that the obligation to protect human rights remains with the State, yet business enterprises, including banks and financial institutions, have a responsibility to respect human rights and responsibilities relative to greater access to remedies for those who are negatively impacted by business activities (UN Human Rights Council 2011; UN General Assembly 2011).

In this respect, the position of the financial sector in respect to potential human rights abuses deserves special attention. In fact, banks can directly abuse the human rights of their employees and customers. However, banks can also be indirectly involved in human rights abuses perpetrated by the business activities of their clients. Accordingly, banks can not only be seen as direct abusers of human rights, but also as complicit in human rights abuses committed by the enterprises that benefitted from their financial support.

As illustrated below, many factors should be considered for establishing which kind of risk a bank is dealing with and what are the possible boundaries a bank should not overcome in order to limit its responsibility. Moreover, nowadays many subjects are involved in this field, as Export credit Agencies (ECAs) or NGOs, playing very different roles in promoting and facilitating banks' compliance process.

\section{The International Sources for the Protection of Human Rights}

As it is universally recognized, the first international source for the protection of human rights is the UN Universal Declaration of Human Rights, adopted by the UN General Assembly on December 1948 and followed in 1966 by the two International Covenants on Civil and Political Rights and on Economic, Social and Cultural Rights.

These three international documents have been considered for a long period of time and are still considered the main collection of human rights rules at a global level. Indeed, since their adoption, the overall framework for the safeguard of human rights was based in these Conventions, whilst at a regional level since 1950 all the international organizations such as the European Union (EU), the African (AU) union and the Organization of the American States (OAS) have adopted Charters and Conventions ${ }^{2}$ related to this issue. Moreover, in the last years also in the Asian continent there have been adopted some documents regarding the protection of individual rights, although the rights included in these conventions are quite different from the ones internationally recognized. ${ }^{3}$

\footnotetext{
${ }^{1}$ Guiding Principles on Business and Human Rights: Implementing the United Nations 'Protect, Respect and Remedy' Framework, March 21, 2011 (UN General Assembly 2011).

2 European Convention for the Protection of Human Rights and Fundamental Freedoms, Rome November 4, 1950 and its Additional Protocols; African Charter on Human and Peoples' Rights (Banjul Charter), Banjul June 27, 1981; American Convention on Human Rights (Pact of San José, Costa Rica), San José November 22, 1969.

3 Arab Charter on Human Rights, adopted by the Council of the Arab League in 1994 and entered into force in January 2008 after seven States ratified the text. According to the United Nations Office for the High Commissioner for Human Rights (OHCHR), the Charter contains provisions that do not meet international norms and standards, such as the application of the death penalty for children.
} 
As far as concerns the topic that the paper is approaching, it is necessary to consider another typology of documents, issued by international organizations (in particular International Financial Institutions-IFIs) and NGOs. That even if not binding, are internationally recognized as voluntary standards. The main ones are the World Bank IFC Performance Standards, the UN Global Compact, the OECD Guidelines for Multinational Enterprises, the ILO Conventions on Child Labour, Forced Labour and Discimination ${ }^{4}$ and the UN "Protect, Respect and Remedy" Framework proposed by Prof. J. Ruggie in 2008 and issued in March 2011, together with the Guiding Principles on Business and Human Rights.

As it is possible to understand the Ruggie's Framework could be considered as the most innovative collection of rules regarding the relation between human rights and business and it demonstrates the emergence of a new trend in this field. Some of the most important concepts that were introduced by the Ruggie's Report is "complicity", that will be explained later in order to understand it in relation with banks' involvement in alleged abuses.

Together with the publication of the last version of the Framework in March 2011, the UN Human Rights Council (2011) has endorsed a new Guiding Principles for Business and Human Rights, providing a global standard for preventing the risk of negative impacts on human rights, linked to business activity. These principles are the product of 6 years of research of prof. Ruggie and consultations with governments, companies, business associations, international experts and civil society from more than 120 countries. They outlined the corrects implementation of the UN "Protect, Respect and Remedy" Framework, appointing some fundamental principles for companies, as the "State Duty to Protect", that recommends to governments how to provide greater consistency of rule for business... on the other side, the "Access to Remedy" principles ensure an adequate accountability and an effective redress, judicial and non-judicial.

The Indirect Involvement of a Bank in an Alleged Human Rights Abuse: The Concept of "Complicity"

A recent study carried out by the Office of the High Commissioner for Human Rights (OHCHR) for the Special Representative J. Ruggie, has documented that $41 \%$ of the 320 cases (from all the world and including all the sectors) collected alleged indirect forms of company involvement in different human rights abuses. In order to understand the increasing relevance of the concept of complicity in the business and human rights context, it is necessary to analyze its meaning as indirect involvement of a company in human rights abuses. Indeed, the term 'involvement' is referred to the aware contribution of the company to another's abuse of human

\footnotetext{
${ }^{4}$ IFC Performance Standards on Environmental and Social Sustainability, January 2012; UN Global Compact Ten Principles; OECD Guidelines for Multinational Enterprises, originally adopted in 1976 and revised several times by the OECD; ILO Convention No. 182 on the Worst Forms of Child Labour, 1999; ILO Convention No. 138 on the minimum age for admission to employment and work, 1973; ILO Declaration on Fundamental Principles and Rights at Work, 1998; ILO Convention No. 111 on Discrimination (Employment and Occupation), 1958; ILO Convention No. 105 on Abolition of Forced Labour, 1957.
} 
rights, whilst the term 'indirect' is referred to the fact that the company itself does not carry out the abuse. Generally, the allegation of company complicity has concerned involvement by State or non-State actors, such as paramilitaries or State officers.

Understanding the implication of complicity, particularly for a bank, involves an appreciation of the role of both the law and the various social actors might have in defining the dimension of complicity, as far as its relevance in a legal and non-legal context. Going directly to the case of a bank, although it could be directly responsible for a human right abuse, it is a very rare case because the majority of banking groups adopt internal policies and standards including due diligence process. Nevertheless, in case of direct liability for an abuse, banks are necessarily subject to the general human rights system it was already explained above. However, the most frequent and dangerous case for banks has become their active role in supporting other business activities, so their behavior is evaluated also regarding whether it contributes to, facilitates or supports human rights abuses (Van Gelder and Vander Stichele 2011a, b).

As far as concerns the legal value of the concept of complicity, on the one hand the legal dimension remains essential, since a Court would necessarily based its judgment on a legal definition of complicity, as it has been defined by the International Commission of Jurists. ${ }^{5}$ On the other hand, public opinion sustain a wider interpretation of complicity, from a moral and ethical point of view, going beyond the possible identification of legal liability. Another concept strictly related to the one of complicity is the risk a bank, or a financial institution in general, could address and that could led to non-compliance of the international human rights standards. The most well-known case studies in this field, as for instance the Doe $v$. Unocal case or the Yahoo! China case, demonstrate a basic pattern of responsibility, related to the relation between the bank and its business/customers. It is possible to identify three different situations involving these subjects, such as:

- Full complicity or joint responsibility $\rightarrow$ this is a project finance case, when the bank typically requires and monitors the social and environmental impact of the project funded and its adherence to the international standards, such as the Equator Principles, ${ }^{6}$ promoted by the IFC. A due diligence process could help the bank in identifying the risk addressed.

- Difficult identification of the complicity existence and extent $\rightarrow$ this is a general loan case, when albeit a bank could be aware that the funded enterprise manufactures products or provides services used for non-legal purposes, it is

\footnotetext{
5 The International Commission of Jurists (ICJ 2008, Expert Legal Panel on Corporate Complicity in International Crime, Corporate Complicity and Legal Accountability, vol 1) identifies the concept of complicity for criminal liability as follows: "three factors are important in determining whether a corporation is complicit in human rights violations. First it should be established that a company's conduct enables, exacerbates or facilitates human rights abuse (causation/contribution). Second, must be demonstrated whether a corporation knew or should have known that its conduct would lead to contribute to human rights violation (knowledge/forseeability). Finally, the proximity to the principal perpetrator of human rights abuse is an important factor (proximity)".

${ }^{6}$ The Equator Principles (EP) is a credit risk management framework realized for determining and managing environmental and social risk in financial transactions. The EP Association released the draft of the updated Equator Principles (EP III) on 13 August 2012 for stakeholder consultation and public comment. It will be online available until October 2012.
} 
almost impossible to ascertain that the landed money was used to produce, for instance, cluster bombs. In this case, legal and ethical responsibility could certainly diverge, but the reputational risk could be very high although it would not always be easy to clarify the relation between banks' involvement and the products and services at risk of human rights abuses.

- Complicity on ethical and legal grounds $\rightarrow$ this is the case of holding or managing financial resources or deposits of States led by dictators. Also in this case, under a legal perspective it is to be proven that the bank knew, or should have known, that the requested payments could have been used for buying the above products or services.

The Unexpected Role of ECAs, National Investment Promotion Agencies and NGOs/CSOs

There are other subjects that play a key role together with private banks in the current financial system, such as the ECAs and the National Investment Promotion Agencies, that are considered also in the UN Framework in respect to their approach to human rights protection. Indeed, after the updated "Common Approaches", 7 with more explicit reference to the Ruggie's Framework, ECAs and National Investment Promotion Agencies throughout the world increasingly consider the respect by business enterprises of environment and human rights as a condition for granting equity funding or credit guarantee facilities. This is proved by the Export Development Canada, the ECA of Canada, that in 2008 published a Statement on Human Rights where it "recognizes that financial institutions must endeavor to assess the potential for adverse human rights outcomes for individuals directly affected by such projects". The Government of Canada now shares intelligence with EDC on the human rights situation for a wide range of Countries. EDC's Political Risk Assessment Department routinely conducts Country- and project-level political risk assessments that include an analysis of factors that influence human rights conditions in host countries. EDC has also nominated a Compliance Officer. The example of Canada is one of the best practices in the world. However, the important role of ECAs in ensuring that businesses do not abuse human right is still a fundamental issue of the Export Credit Group of the OECD (ECG) discussions.

On the other hand, the Italian ECA, SACE, has adopted the 'Environmental Guidelines', consistent with the Common Approaches, since 2001. These Guidelines define an environmental impact assessment procedure to evaluate potential ecological impacts of Italian businesses project supported by SACE. Also SIMEST (the Italian Credit and Investment Promotion Agency) has adopted an environmental policy, complementary to the SACE's one, and issued two directives consistent with the current Common Approach.

\footnotetext{
7 The Export Credit Group of the OECD (2010) has revised on June 2012 the Recommendations on Common Approaches on the Environment and Officially Supported Export Credits, in order to respond to the need to integrate human rights into the current Common Approaches, as suggested by Jonh Ruggie ECAs "should clearly acknowledge that human rights are a critical element in the social sustainability of enterprises and markets, and explicitly recognize ECAs' role in fostering the corporate responsibility to respect human rights".
} 
As far as concerns NGOs and CSOs, it is impossible to report with precision the growing number of human rights organizations specifically dedicated to the impact of private banks' activities on human rights. The field is growing every day, due to the new-born specialized organizations flourishing around the world as far as expert sections established in human rights NGOs. ${ }^{8}$ Arguably, an indirect measure of the growing number of organizations is their diversification.

There are three main forms of human rights organizations dedicated to banks and human rights. First, there are what we can call 'information hubs'. Such organizations run free website where they upload the greatest possible amount of information about banks and human rights abuses. The most prominent example is the Business and Human Rights Resource Centre, ${ }^{9}$ that offers three different sections covering banks and human rights: 'Finance and Banking', specific private companies section, Corporate Legal Accountability Portal.

The second type of NGOs dedicated to banks and human rights can be properly called the 'watchdogs'. The most important of these NGOs is named BankTrack (2010), ${ }^{10}$ a global network of civil society organizations and individuals tracking the operations of the private financial sector (commercial banks, investors, insurance companies, pension funds) and their effects on people and the planet. Such organizations advocate for better corporate practices, conduct independent (and often critical) research on projects and policy developments within the private financial sector, and educate civil society on the activities of the private financial sector and their effect on people and the environment. Other prominent advocacy NGOs are BankWatch, Netwerk Vlaanderen and the Berne Declaration. ${ }^{11}$

The last type of human rights organization dedicated to banks and human rights are what can be called 'accountability organizations'. These organizations assist communities around the world to defend their human rights. Fundamentally, they conduct trainings for local communities about the mechanisms available to hold international financial institutions and corporations accountable. Trainings for a particular community may cover a company's own social and environmental rules, the rules of their financial sponsors, compliance systems, and guidance as to the drafting of the community's grievance to such accountability mechanisms. An example of this type of organization is Accountability Counsel. ${ }^{12}$

To conclude, it is important to recall the work by a myriad of small, local human rights NGOs often located in-and advocating for-the developing Countries poorest and weakest communities. They may not be specifically dedicated to banks. Yet, without the first-hand information they provide, the work by international and prominent human rights NGOs would be impossible, and information on peripheral abuses could hardly reach the international media.

\footnotetext{
${ }^{8}$ Frankel P., Amnesty International and Albin-Lackey C., Human Rights Watch.

9 http://www.business-humanrights.org.

${ }^{10} \mathrm{http}: / / \mathrm{www} \cdot$ banktrack.org.

11 http://www.bicusa.org; http://www.bankwatch.org; http://www.netwerkvlaanderen.be; http://www. evb.ch.

12 http://www.accountabilitycounsel.org.
} 
Human Rights as a Parameter for Rating Agencies Evaluation

Presently, the rating Agencies, in order to meet the needs of stakeholders to screen companies on both financial and non-financial parameters, have developed a sustainability analysis that monitor the performance of the companies also with regard to their respect of environment, community relations, human resources management, ethics and business behavior, stakeholder engagement, human rights, control on the value chain and other related areas.

The assessment is conducted basing on criteria identified by the rating Agencies aimed at reflecting international best practices. Companies to be listed in the Dow Jones Sustainability Indexes (launched in 1999) have to meet criteria (economic, environmental and social) set by the Swiss rating Agency SAM (Sustainable Asset Management) that adopts the 'best-in-class' approach, which selects the best companies in each sector from the ones listed on global and regional Dow Jones Indexes, to be included in the relevant Sustainability Indexes.

Also FTSE works in association with an independent service (the Ethical Investment Research Service-EIRIS) to identify companies to be included in FTSE All-Share Index; that can be also counted in the FTSE4Good. Companies to be scrutinized on the basis of EIRIS criteria have to (1) work towards environmental sustainability; (2) develop positive relationships with stakeholders; (3) up-hold and support universal human rights; (4) ensure good supply chain labor standards; and (5) counter bribery.

Scrutiny of the sustainability of companies is carried out also by other Agencies in Europe.

All companies included in the Euro STOXX Index holding over $50 \%$ of the total market capitalization of other eligible companies can be included in the ASPI Eurozone Index. The inclusion depends on the respect of criteria rated by VIGEO in six areas: human resources, governance, business behavior, environment, philanthropy and human rights. Information on the social and environmental performance of companies are provided also by Oekom, an independent ratings Agency, managing the Global Challenges Index, which includes companies facing global challenges (climate changes, adequate provision of drinking water, deforestation, biodiversity, population development, poverty, responsible governance structures) and promoting sustainable development.

Of course the inclusion in the above sustainability indexes has no legal value, nonetheless businesses and banks rightfully estimate that non-inclusion or rejection could affect their image and reputation in respect to customers and other stakeholders. It is also to be remarked that the rating Agencies basically require the establishment of a process of aggressive compliance and, at the least the adoption of a policy statement.

\section{Conclusion}

While it might be hard to affirm that the number of cases of human rights abuses involving banks have sharply increased over the last 10 years, some other 
interesting points help in better evaluating the trends of banks' involvement. For instance, although the presence of banks in large scale projects is consider essential by CSOs, in these cases bank complicity is more easily proved. For this reason, the top private international banks endorsed the most relevant standards, like the Global Compact and the Equator Principles, that confirms their increasing awareness for the respect of human rights. Moreover, it is interesting to underline that banks have been historically linked to human rights abuses mostly in cases of project finance, but in recent years they have been called to respect human rights in an extremely wider scope of operations, as for instance their relationship with employees and customers and in lending activities (Roca and Manta 2010).

Regarding the dimension of damages suffered by a bank, quantification of both reputational and economic damages remains hard. On one side, in many cases of alleged abuses the bank suffers an economic damage because of the cancellation or the deeply restructuration of the projects funded, whilst in others the banks were driven to withdraw. However, some relevant costs are certainly accepted by the banks involved, as for example the ones to face a lawsuit or to bear litigation costs.

On the other hand, reputational risk is listed as one of the most significant threat to businesses from risk management teams, but it does not exist a satisfactory and unique description of this risk yet. One of the most preeminent approaches comes from the Committee of European Banking Supervisors, ${ }^{13}$ which stated that "reputational risk is defined as the current or prospective risk to earnings and capital arising from adverse perception of the image of the financial institution on the part of clients, counterparties, shareholders, investors or regulators". The Economist Intelligence Unit defined the role of reputational risk not as a danger, but rather as an opportunity, being "the most valuable asset in the capitalist economy: it is not cash, stock or buildings, but trust". ${ }^{14}$

What is important to focus is that reputational risk can take place in different forms, implying the possibility that a loss occurs in the values of the financial intermediary. Such losses manifest in various activities and can also imply additional costs for the financial intermediary. Sources of reputational risk can be both internal or external, with respect to the activities of the financial institution, meaning that awareness of potential damages is a key issue to be addressed in managing risk causes. Furthermore, it is presently impossible to identify all the single consequences a reputational failure can have for a financial institution in international markets, even if there is a growing attention on themes of sustainability. Indeed, indexes such as Dow Jones Sustainability Indexes (DJSI), FTSE100 or Asset 4 take into consideration the sustainability performance of major companies in the market, focusing their attention on the analysis of corporate economic, environmental and social performance, assessing issues such as corporate governance, risk management, branding, climate change mitigation, supply chain standards and labor practices.

In conclusion, it is possible to affirm that in order to identify the human rights potentially infringed by enterprises and banks in particular, all the international

${ }^{13}$ Committee of European Banking Supervisors, CP03 revised (2005).

14 Economist Intelligence Unit, Reputation: Risk of Risks (2005). 
sources, as described in "The international sources for the protection of human rights", could be considered as relevant for evaluating which rights have been violated and the bank legal responsibility.

As far as concerns complicity, it is no longer a legal concept (aiding or abetting) but is now also a parameter of a responsibility/commitment relation between the banks and the civil society. On one hand, CSOs and public opinion in general tend to consider banks as complicit whenever they provide funds to enterprises or other subjects (like for instance countries), that are committing-or are alleged to commit-human rights abuses. On the other hand, banks themselves do no longer deny their key role in promoting human rights compliance. Understandably, when they respond to allegations of human rights abuses, they just try to avert the primary responsibility, albeit letting the awareness of their responsibility emerge.

\section{References}

Banktrack (2010) Human Rights responsibilities of private sector banks. The policy required to "Respect" and provide "Access to remedy"-Submission to Professor John Ruggie, United Nations Special Representative of the Secretary-General on the issue of human rights and transnational corporations and other business enterprises

Committee of European Banking Supervisors (2005) CP03 revised

Economist Intelligence Unit (2005) Reputation: Risk of Risks, 4th report

International Commission of Jurists (2008) Expert Legal Panel on Corporate Complicity in International Crime, Corporate Complicity and Legal Accountability, vol 1

OECD (Organization for Economic Cooperation and Development) (2010) 10th Roundtable on Corporate Responsibility, Updating the Guidelines for Multinational Enterprises, Discussion Paper

Roca R, Manta F (2010) Danish Institute for Human Rights, Values added: the challenge of integrating human rights into the financial sector

UN General Assembly (2011) Guiding Principles on Business and Human Rights: Implementing the United Nations "Protect, Respect and Remedy" Framework

UN Human Rights Council (2011) Report of the Special Representative of the Secretary-General on the issue of human rights and transnational corporations and other business enterprises, John RuggieGuiding Principles on Business and Human Rights: Implementing the United Nations "Protect, Respect and Remedy" Framework

Van Gelder JW, Vander Stichele M (2011a) How to integrate. Sustainability criteria in capital requirements, Banktrack

Van Gelder JW, Vander Stichele M (2011b) Why to integrate. Sustainability criteria in capital requirements, Banktrack

http://www.accountabilitycounsel.org

http://www.banktrack.org

http://www.bankwatch.org

http://www.bicusa.org

http://www.business-humanrights.org

http://www.equator-principles.com

http://www.evb.ch

http://www.ftse.com

http://www.netwerkvlaanderen.be

http://www.sustainability-index.com 